\title{
Complementaridade de fatores: contribuições para um novo olhar em torno da velhice*
}

Fátima Ferretti, Clodoaldo Antônio

de Sá, Vanessa da Silva Corralo

FisiSenectus. Unochapecó Ano 4, n. 1 - Jan/Jun. 2016 p. 1-3

0 processo de envelhecer se constitui imbricado de aspectos biológicos, psicológicos, sociais e culturais ${ }^{1}$. O lugar e a sociedade em que nascemos e vivemos ao longo da vida são fatores determinantes para o modo como envelheceremos tanto quanto o nosso código genético, que determinará aspectos da nossa saúde física. Não basta, portanto, descrever de maneira analítica os diversos aspectos da velhice: cada um deles reage sobre todos os outros e é afetado por eles; é no movimento indefinido desta circularidade que é preciso apreendê-la ${ }^{1}$.

No contexto atual, o que marca o debate atual acerca do envelhecimento são, dois modelos antagônicos de pensar.

No primeiro deles, trata-se de construir um quadro apontando a situação de pauperização e abandono a que o velho é relegado, em que ainda é, sobretudo, a família que arca com o peso dessa situação. Esse modelo é criticado porque estaria, sem pretender, alimentando os estereótipos da velhice [..]. No segundo, trata-se de apresentar os idosos como seres ativos, capazes de dar respostas originais aos desafios que enfrentam em seu cotidiano, redefinindo sua experiência de forma a se contrapor aos estereótipos ligados à velhice ${ }^{2}$.

Ainda, cabe destacar que, do ponto de vista econômico, os idosos se configuram hoje como um mercado crescente e promissor de bens de consumo, cultura, lazer, estética, serviços de prevenção e reabilitação em saúde. Do ponto de vista social, constituem-se como novos emergentes sociais, com poder de influir em seus destinos, por sua significância numérica e qualitativa, por meio da conquista de leis e benefícios ${ }^{2,3}$.

Beauvoir ${ }^{1}$ destaca que para uma boa velhice deve-se continuar a perseguir fins que deem sentido a nossa vida, como a dedicação a indivíduos, a coletividades, a causas, trabalho social ou político, intelectual e criador. Contrariamente ao que aconselham os moralistas, é preciso desejar conservar na última idade paixões fortes. A vida conserva seu valor enquanto atribuímos um valor à vida dos outros, por meio do amor, da amizade, da indignação, da compaixão.

Atualmente os idosos, na certeza de que hoje não podem viver como antigamente, ocupam e redefinem os novos espaços criados para envelhecer, respondendo de maneiras diversas ao tipo de controle de emoções que passa a ser exigido deles ${ }^{2}$. E, dessa forma, têm conseguido romper com alguns preconceitos e estabelecer novas formas de viver, assumindo novos papéis neste momento da vida. 
Por outro lado, há a tese atual de que a velhice é um problema por si só, capaz de sobrepor-se a diferenças socioeconômicas e étnicas, e, por isso, a tendência é propor recortes em estágios do envelhecimento baseados na idade e na independência funcional.

Na sociedade ocidental, não somente o ciclo da vida é socialmente padronizado como também seu curso passa, cada vez mais, a ser regulado pelo Estado, a despeito das potencialidades e dos problemas de cada um. A infância, a adolescência e a juventude são tempos de escolarização; a idade adulta é o tempo associado à procriação e à participação no mercado de trabalho; a velhice, o tempo da aposentadoria ${ }^{3}$.

Já, Debert ${ }^{2}$ (p. 95) afirma que "não é o avanço da idade que marca as etapas mais significativas da vida; a velhice é, antes, um processo contínuo de reconstrução" e desta forma situa que a idade cronológica não é um marcador significativo. Desse modo, pode-se salientar que o envelhecimento não parece ser definido pela idade de uma pessoa, mas pelos efeitos que essa idade e suas vivências teriam causado em sua vida.

A cronologização do ciclo de vida foi responsável pela instituição de segregações entre as etapas, definindo quando se dá a passagem de uma para outra e os comportamentos esperados em cada período da vida. Desse modo, quando completa-se um determinado número de anos, o ser humano é captado por algumas imagens e certas práticas sociais. Portanto, a idade que julgamos ter não é nossa, mas sim construída. É, na verdade, do outro, mas define o seu papel social no grupo. Nesse sentido, pertencer a um grupo de idade significa estar conforme as normas daquele grupo, saber o que se pode ou não fazer, reconhecer o que os outros esperam que façamos, que comportamentos sejam aceitáveis ou não ${ }^{4}$.

Atualmente, no entanto, a idade já não tem sido fator determinante para definir a velhice. Porém, durante muito tempo, a juventude foi eleita como idade-padrão e a víamos associada às categorias de desenvolvimento, de mudança social, de padrões estéticos, a ponto de se estabelecer contiguidade entre as ideias de jovem, de belo, de moderno, saudável e de progresso. Estas imagens construídas fortaleciam uma percepção negativa da velhice. Há que se ponderar que esta situação aos poucos vem sendo modificada e os idosos vêm ocupando um papel mais protagonista no contexto social. Também figuram como um amplo mercado consumidor e as empresas têm considerado esta tendência na hora de criar novos produtos. Ainda, este segmento vem assumindo um papel ativo no debate de direitos e políticas que contribuam com o envelhecimento bem-sucedido, todo um cenário que demonstra uma nova tendência assumida pelos idosos no convívio em sociedade, saindo do ostracismo e do isolamento social.

Embora as várias correntes teóricas discutam o processo de envelhecimento com base em diferentes pressupostos sejam de natureza biológica, psicológica ou social, na atualidade há o reconhecimento da interdependência e complementaridade dessas diferentes dimensões na forma como cada ser envelhece e, ainda, que este é um processo complexo e multidimensional. Todos os fatores que constituem a existência humana, como a história, o aporte genético, a cultura, o meio ambiente e a sociedade onde este ser humano viveu e conviveu, são constituintes do processo de viver e envelhecer e, desse modo, igualmente determinantes no processo de envelhecimento. Nesse sentido, é importante destacarmos que o debate em torno do envelhecimento evoluiu com todas as teorias e concepções apresentadas e saímos de um entendimento mais reducionista para uma compreensão global e multidimensional do processo.

Como Ramos ${ }^{5}$ destaca, nesse sentido, o almejado envelhecimento bem-sucedido depende do equilíbrio entre as várias dimensões que são resultantes dessa interação multidimensional entre saúde física, saúde mental, independência na vida diária, integração social, suporte familiar e independência econômica, sem necessariamente significar ausência de problemas em todas as dimensões. 
Assumimos na atualidade a velhice como um momento da vida no qual as trajetórias de cada indivíduo, marcadas pelas experiências vivenciadas o tornam único, quer sob o ponto de vista biológico, psicológico ou social. Dessa forma, estudar o envelhecimento sob a perspectiva individual ou coletiva requer necessariamente uma abordagem interdisciplinar, em que se estabeleça uma inter-relação entre os conhecimentos produzidos pelas teorias biológicas, psicológicos, culturais, históricos, ambientais e sociais, para que se compreenda esse fenômeno assumindo que ele ocorre de forma diferente para cada ser humano, e, que esta complementaridade de saberes se constitui como um fator determinante para desenvolver pesquisas e intervenções para essa área.

Quando compreendemos o que é a condição dos velhos, não podemos contentar-nos em reivindicar uma 'política da velhice' mais generosa, uma elevação das pensões, habitações sadias, lazeres organizados. É todo o sistema que está em jogo, e a reivindicação só pode ser radical: mudar a vida ${ }^{1}$.

Esse entendimento coloca o estudo do envelhecimento, não como um tema multidisciplinar, mas sim, interdisciplinar a todas as áreas de conhecimento. Como resultado prático, é de se esperar que grupos de profissionais das diversas áreas se aproximem para planejar estudos acerca do envelhecimento, utilizando diferentes metodologias e abordagens, considerando a necessidade de manter esse diálogo entre as teorias, para que se possa compreender a complexidade desse tema em toda sua amplitude e, que de fato, tenhamos a partir dessa concepção emergente uma produção de conhecimentos que realmente melhore a vida do ser humano, em qualquer fase, desde a concepção até a morte, pois a velhice é construída ao longo de toda a vida.

\section{Nota}

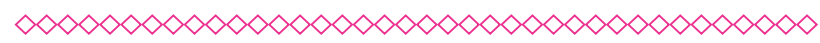

* Ferretti F, De Sá CA, Corralo VS. Envelhecimento: um fenômeno contemporâneo, complexo e multidimensional. In: De Sá CA, Ferretti F, Busato MA. Ensaios contemporâneos em saúde: uma perspectiva interdisciplinar. Chapecó: Argos; 2013. p. 93-112.

\section{Referências}

$\infty \times \infty \times \infty \times \infty \times \infty \times \infty \times \infty \times \infty \times \infty \times \infty \times \infty \times \infty$

1. Beauvoir SA. A velhice. Rio de Janeiro: Nova Fronteira; 1990.

2. Debert GG. A reinvenção da velhice. São Paulo: Editora da Universidade de São Paulo-Edusp; 2004.

3. Minayo MCS, Coimbra Jr CE. Antropologia, saúde e envelhecimento. Rio de Janeiro: Fiocruz; 2002.

4. Buaes $C$. $O$ envelhecimento e a viuvez da mulher num contexto rural: algumas reflexões. RBCEH, 2007;4(1):103-114.

5. Ramos LR. Fatores determinantes do envelhecimento saudável em idosos residentes em centro urbano: Projeto Epidoso, São Paulo. Cad. Saúde Pública. 2003 Jun;

19(3):793-797. 